\title{
FIRST BREEDING RECORD OF THE EARED GREBE IN SONORA, MEXICO
}

RYAN P. O'DONNELL, Arizona Game and Fish Department, 5000 W. Carefree Highway, Phoenix, Arizona 85086; rodonnell@azgfd.gov

KYLA GARTEN, Hansen Biological, 4200 N. Freeway Boulevard, Suite 4, Sacramento, California 95834

The Eared Grebe (Podiceps nigricollis) is the most widespread and abundant grebe worldwide, with a distribution that includes Asia, Africa, Europe, and North America. In North America, the species breeds widely through the western and central United States and southern Canada. There is also a small, disjunct, and poorly known breeding population in the highlands of the volcanic belt of central Mexico (Wilson et al. 1988). Away from this population, breeding in Mexico is sporadic, with scattered records from Chihuahua, Nayarit, Jalisco, and Puebla (Dickerman 1969, Williams 1982). A former breeding population in Baja California had been presumed extirpated (Huey 1928, Cullen et al. 1999), but recently breeding has been documented annually in Mexicali (Erickson et al. 2011, Mellink and Hinojosa-Huerta 2018). In Sonora, there are infrequent summer records but no previous breeding records (Russell and Monson 1998; eBird.org).

On 2 and 3 September 2018 we observed an adult Eared Grebe in breeding plumage feeding a downy juvenile in the sewage-treatment lagoons at Puerto Peñasco ("Rocky Point"), Sonora, at $31.320^{\circ} \mathrm{N}, 113.495^{\circ}$ W (Figure 1). Although we did not see the nest, the flightless juvenile had to have hatched locally. The shores of the lagoons were lined with ample emergent vegetation suitable for nesting. We did not observe the juvenile riding on the adult's back, but it was being fed frequently and therefore was likely 7 to 20 days old (Cullen et al. 1999).

Late August is relatively late in the season for nesting, and most Eared Grebes have concluded breeding by that time, but the timing of breeding in this species is notably variable (Cullen et al. 1999). In particular, late summer and early fall rains have induced

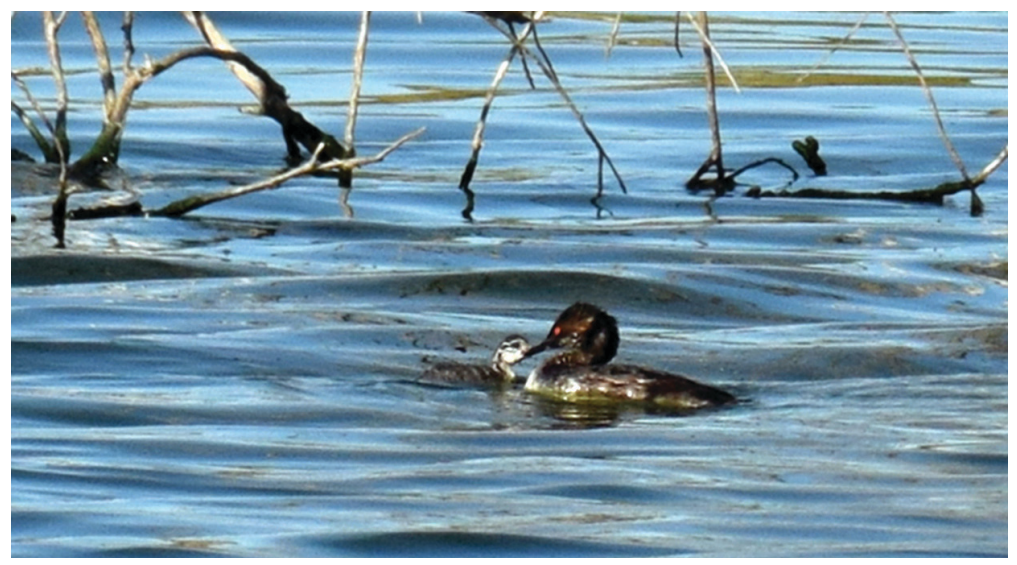

Figure 1. Adult Eared Grebe feeding a chick at the municipal sewage lagoons, Puerto Peñasco, Sonora, Mexico. This represents the first documented breeding of the species in the state of Sonora.

Photo by Ryan P. O'Donnell 


\section{NOTES}

breeding in areas where water levels otherwise had been too low (Wilson et al. 1988). Breeding in northern Sonora might have been prompted by an unusually productive monsoon season in 2018, although we suspect water levels at this sewage-treatment facility are regulated so that rains did not have an appreciable effect on water levels. This breeding at Puerto Peñasco narrows the significant gap in the species' known breeding range between Arizona to the north, Chihuahua to the east, Baja California to the west, and Nayarit to the south.

We thank Lin Piest for coordinating our trip to the region for the study of the Flat-tailed Horned Lizard (Phrynosoma mcallii) and Troy Corman for helpful comments on an earlier draft.

\section{LITERATURE CITED}

Cullen, S. A., Jehl, J. R. Jr., and Nuechterlein, G. L. 1999. Eared Grebe (Podiceps nigricollis), in The Birds of North America (A. F. Poole and F. B. Gill, eds.), no. 433. Birds N. Am. Inc, Philadelphia; doi 10.2173/bna. 433.

Dickerman, R. W. 1969. Nesting records of the Eared Grebe in Mexico. Auk 86:144; doi $10.2307 / 4083560$.

Erickson, R. A., Carmona, R., and Ruiz-Campos, G. 2011. Baja California peninsula. N. Am. Birds 64:90-91.

Huey, L. M. 1928. Some bird records from northern Lower California. Condor 30:158-159.

Mellink, E., and Hinojosa-Huerta, O. 2018. Breeding waterbirds of the Mexican portion of the Colorado River delta, in Riparian Research and Management: Past, Present, Future (R. R. Johnson, S. W. Carothers, D. M. Finch, K. J. Kingsley, and J. T. Stanley, tech. eds.), vol. 1, pp. 174-187. U.S. Forest Service Gen Tech. Rep. RMRS-GTR-377, Rocky Mountain Res. Sta., Fort Collins, CO.

Russell, S. M., and Monson, G. 1998. The Birds of Sonora. Univ. Ariz. Press, Tucson.

Williams, S. O. III. 1982. Notes on the breeding and occurrence of Western Grebes on the Mexican Plateau. Condor 84:127-130; doi 10.2307/1367839.

Wilson, R. G., Hernandez, C., and Melendez, A. 1988. Eared Grebes nesting in the Valley of Mexico. Am. Birds 42:29. 